\title{
MEASURING OF THE ALTERATION OF RETROTRANSPOSITION IN THE RESPONSE OF SALINITY STRESS USING IRAP AND SCOT MARKERS
}

\author{
Marwa M. Shehata*, Eman M. Fahmy, Fatma M. Badawy \\ and Lamyaa M.K. Sayed \\ Genetics Dept., Fac. of Agric., Ain Shams Univ., P.O. Box 68, Hadayek Shubra 11241, \\ Cairo, Egypt
}

*Corresponding author: marwa gene@agr.asu.edu.eg

Received 30 October, 2019

Accepted 2 December, 2019

\begin{abstract}
Retrotransposons comprise the major part of eukaryotic genomes. They have the ability to replicate themselves through RNA intermediate via reverse transcription process. During normal development, these elements become quiescent, but they are stimulated by stresses. The availability of PCR-based techniques to detect the variation in retrotransposition rate due to salinity was tested. IRAP and SCoT markers were applied in two salinity-tolerant eukaryotic genomes: Yeast (Saccharomyces cerevisiae L.) and Barley (Hordeum vulgare L.). The genomes of the yeast strain EMCC49 and two barley cultivars Giza-123 and Giza2000 were extracted. Five IRAP primers with two combinations and nine SCoT primers were applied. The yeast strain was grown in the YPG media with $0.5 \mathrm{M}, 1 \mathrm{M}, 1.5 \mathrm{M} \mathrm{NaCl}$ or the control. The barley cultivars were irrigated with $0.25 \mathrm{M}, 0.6 \mathrm{M}$ $\mathrm{NaCl}$ or just distilled water. IRAP technique developed three markers in the yeast under the different levels of salinity. ScM1 IRAP primer showed a band with molecular size of $456 \mathrm{bp}$ in the yeast under 0.5 and $1.5 \mathrm{M}$ only. Another band with molecular size of $409 \mathrm{bp}$ appeared under the control and disappeared in all salinity treatments. The third IRAP marker was shown by the ScM2 primer with molecular size of 1952 bp under the $0.5 \mathrm{M}$ treatment. While, two IRAP markers appeared in barley due to high salt conditions. The 5'LTR IRAP primer showed an 886 bp band in the barley cultivar Giza2000 under the control condition only. Sukkula IRAP primer displayed the second IRAP marker in the cultivar Giza-2000 of barley with molecular size of $330 \mathrm{bp}$ under the $0.6 \mathrm{M}$ only. SCoT markers
\end{abstract}

showed 17 markers in the response of salinity stress in yeast with molecular sizes ranged from 1911 to 271 bp with SCoT 31 and SCoT 26 primers, respectively. SCOT 26 primer gave the highest number of markers per SCoT primer (five different markers). In barley, 18 SCoT markers were detected under high salt conditions. They molecular sizes were between 1762 (SCoT 26) and 281 bp (SCoT 7). SCoT 32 primer showed five markers in barley under salinity as the highest number of markers per SCOT primer. The results showed different patterns between control and treatments and the high levels of salinity led to new retrotransposition. This study confirmed that PCR techniques; like IRAP and SCoT can exhibit the activation of retrotransposition due to high salt conditions. Good positive results were obtained and we recommend using these techniques for different molecular purposes due to their advantage; easy, fast, cheap and effectiveness.

Keywords: Retrotransposon, salinity, IRAP and SCoT techniques

\section{INTRODUCTION}

Transposable elements comprises about of $3 \%$ from the Saccharomyces cerevisae, 15\% of Arabidopsis thaliana, $20 \%$ of Drosophila melanogaster, $45 \%$ of Homo sapiens and $80 \%$ of Zea mays genomes (Kim et al 1998; Smit, 1999; Lander et al 2001; Kaminker et al 2002; Sabot and Schulman, 2006; and Maumus et al 2009). The majority components of most plant genomes are retrotransposons (Mansour, 2007). Retrotransposons are detected in all eukaryotes 
(SanMiguel et al 1998). Retrotransposons are found in a random distribution in the genome (Bayram et al 2012). Retrotransposons use the "copy and paste" mechanism in its replication. They replicate via reverse transcription using an mRNA intermediate (Ikeda et al 2001; Maumus et al 2009).

Retrotransposons seem the lentiviruses in its structure and life cycle (Feschotte et al 2002; Kalendar and Schulman, 2006; Sabot and Schulman, 2006). Most retrotransposons produce proteins which are needed for their own retrotransposition (Bayram et al 2012). Both of Kalendar et al 2000; Sabot and Schulman, 2006 and Sabot et al 2006 reported that retrotransposons that didn't have these proteins use the proteins encoded from another retrotransposons. Retrotransposons integrate themselves to many loci inside the genome. They produce polymorphism among individuals (Bonchev et al 2010). The methylation is one of different mechanisms that cause inactivated majority of retrotransposons during development (Hirochika et al 2000).

Mansour 2009 and Alzohairy et al 2012 discussed the role of stress in the enrichment of the retrotransposition rate. Stress leads to production larger pools of transcripts of retrotransposons (Mansour 2007, 2008 and Salazar et al 2007). Bayram et al 2012 stated that activation of retrotransposons can stimulate due to the effect of some stress conditions. Salazar et al 2007 found that the promoters of retrotransposons play the main role in the success of retrotransposition process.

SCoT or "start codon targeted" marker is a PCR-based technique for detection polymorphism developed by Collard and Mackill, 2009. SCoT analysis depends on the short conserved regions around the start codon. Al-qurainy et al 2015 stated that SCoT markers became one of the best choices to study the genetic diversity. Wu et al 2013 counts the advantages of the SCOT technique. They reported that SCoT marker is simple, rapid, cheap, effective, repeatable, and reproducible. IRAP or "Inter retrotransposon amplified polymorphism" technique amplify the distance between two LTR-retrotransposons (Kalendar and Schulman, 2006).

The purposes of the present study were to study the effect of salinity on the activation of retrotransposition rate in different eukaryotic organisms such as higher-flowering-plants (barley) and lowering-eukaryotic single-cell organisms (yeast) and to test the effectiveness of IRAP and SCoT markers in the detection of retrotransposition and distinguish their banding patterns differences due to salt-activated retrotransposons.

\section{MATERIALS AND METHODS}

\section{Yeast strain and barley cultivars}

One yeast (Saccharomyces cerevisiae L.) strain and two barley (Hordeum vulgare L.) cultivars (Table 1) were used to study the effect of salinity stress on the activation of retrotransposition.

Table 1. The names and sources of the yeast strain and barley cultivars

\begin{tabular}{|c|c|}
\hline Name & Source \\
\hline EMCC-49 & $\begin{array}{c}\text { Microbiological Resources Centre } \\
\text { (Cairo MIRCEN) }\end{array}$ \\
Giza-123 & $\begin{array}{c}\text { Field Crop Research Institute, } \\
\text { Agricultural Research Center } \\
\text { Giza-2000 }\end{array}$ \\
\hline
\end{tabular}

\section{IRAP- and SCoT-PCR techniques}

\section{DNA extraction and PCR-amplification}

Pure culture for EMCC-49 yeast strain was grown in YPG medium; yeast extract, pepton and glucose (Curran and Bugeja, 2006) on a water bath with shaker at $30^{\circ} \mathrm{C}$ for $48 \mathrm{~h}$. The control medium without any salt and treated media with high salt concentrations, $0.5 \mathrm{M}, 1 \mathrm{M}$ or $1.5 \mathrm{M} \mathrm{NaCl}$. Then, the genomic DNA was isolated using a method described by Beringer (1974). Barley cultivars treated with high levels of salinity $(0.25 \mathrm{M}$ or $0.6 \mathrm{M} \mathrm{NaCl}$ ) and the genomic DNA was isolated from leaves after nine days of treatment using a method described by Dellaporta et al (1983).

Five IRAP primers were used in this study. Two (ScM1 and ScM2) were applied with their combination on yeast (Table 2). While, the other three (LTR, Sukkula and WLTR 2105) with their combinations were used with the two barley cultivars as shown in Table (3).

For SCoT technique nine SCOT primers were used with both yeast and barley. Table (4) represents the names and the sequences of the nine SCOT primers. 

Stress using IRAP and SCoT Markers

Table 2. The names and the sequences of yeast IRAP primers

\begin{tabular}{|c|c|}
\hline Primer & Sequence \\
\hline ScM1 & 5' GCTGTCATCGAAGTTAGAGG 3' \\
ScM2 & 5' AGAAGATGACGCAAATGATGAG 3' \\
\hline
\end{tabular}

Table 3. The names and sequences of barley IRAP primers

\begin{tabular}{|c|c|}
\hline Primer & Sequence \\
\hline \multirow{2}{*}{ 5'LTR } & 5' ATCATTGCCTCTAGGGCATAA \\
Tukkula 3' & 5' GATAGGGTCGCATCTTGGGCGT \\
& GAC 3' \\
Wltr2105 & 5' ACTCCATAGATGGATCTTGG \\
TGA 3' \\
\hline
\end{tabular}

Table 4. The names and sequences of barley and yeast SCoT primers

\begin{tabular}{|c|c|}
\hline Primer & Sequence \\
\hline SCoT 5 & 5' CAACAATGGCTACCACGA 3' \\
SCoT 7 & 5' CAACAATGGCTACCACGG 3' \\
SCOT 18 & 5' ACCATGGCTACCACCGCC 3' \\
SCoT 22 & 5' AACCATGGCTACCACCAC 3' \\
SCoT 26 & 5' ACCATGGCTACCACCGTC 3' \\
SCoT 31 & 5' CCATGGCTACCACCGCCT 3' \\
SCoT 32 & 5' CCATGGCTACCACCGCAC 3' \\
SCoT 34 & 5' ACCATGGCTACCACCGCA 3' \\
SCOT 35 & 5' CATGGCTACCACCGGCCC 3' \\
\hline
\end{tabular}

To perform PCR reactions, $10 \mu \mathrm{l}$ master mix, 4 $\mu \mathrm{l}$ DNA, $2 \mu \mathrm{l}$ primer and $4 \mu \mathrm{l} \mathrm{H} 2 \mathrm{O}$ for $20 \mu \mathrm{l}$ total volume were used. The PCR reaction for all techniques was the same with the exception of annealing temperature as the follow: initial denaturation at $94^{\circ} \mathrm{C}$ for 5 minutes only on time, 35 cycles, denaturation step at $94^{\circ} \mathrm{C}$ for 30 second, annealing temperature; step two was $50^{\circ} \mathrm{C}$ or $61^{\circ} \mathrm{C}$ for 45 second, extension step at $72^{\circ} \mathrm{C}$ for 1 minute, finally the final extension was at $72^{\circ} \mathrm{C}$ for 10 minutes.
Where for SCoT primers; for yeast and barley and IRAP for yeast the annealing temperature was $50^{\circ} \mathrm{C}$ whereas, it was $61^{\circ} \mathrm{C}$ for barley IRAP. The PCR products were running using $1.5-2 \%$ agarose concentration, staining with ethidium bromide to visualize by UV.

\section{RESULTS AND DISCUSSION}

In this study, yeast strain and barley cultivars were used as models of eukaryotic organisms to study the effect of salinity as an environmental stress on activation of retrotransposons. Two techniques were used, each of them for a certain purpose. IRAP technique was used to determine if new retrotranspositions occurs under the effect due to salt stress. Whereas, SCOT markers were used to detect the effect of retrotransposition on coding regions; up or down regulation for these regions.

\section{IRAP for yeast strain and barley cultivars}

IRAP primers and their combinations were used with the yeast strain (EMCC-49) and barley cultivars (Giza-123 and Giza-2000) (Table 1). For yeast ScM1, ScM2 primers and the combination between them were used to apply IRAP technique (Fig. 1 and Table 5). Whereas, 5'LTR, Sukkula, Wltr2105 and the combination between 5'LTR and Sukkula primers were used with barley for the same purpose (Fig.1 and Table 6).

Table 5. The molecular sizes of different bands of yeast IRAP primers

\begin{tabular}{|c|c|c|c|c|c|}
\hline Primer & Bp & C & T1 & T2 & T3 \\
\hline \multirow{2}{*}{ ScM1 } & 456 & 0 & 1 & 0 & 1 \\
& 409 & 1 & 0 & 0 & 0 \\
ScM2 & 1952 & 0 & 1 & 0 & 0 \\
\hline
\end{tabular}

Table 6. The molecular sizes of different bands of barley IRAP primers

\begin{tabular}{|c|c|c|c|c|c|c|c|}
\hline \multirow{2}{*}{ Primer } & \multirow{2}{*}{ Bp } & \multicolumn{3}{|c|}{ Giza-123 } & \multicolumn{3}{c|}{ Giza-2000 } \\
\cline { 3 - 8 } & & C & T1 & T2 & C & T1 & T2 \\
\hline \multirow{2}{*}{ LTR } & 886 & 0 & 0 & 0 & 1 & 0 & 0 \\
Sukkula & 330 & 0 & 0 & 0 & 0 & 0 & 1 \\
\hline
\end{tabular}




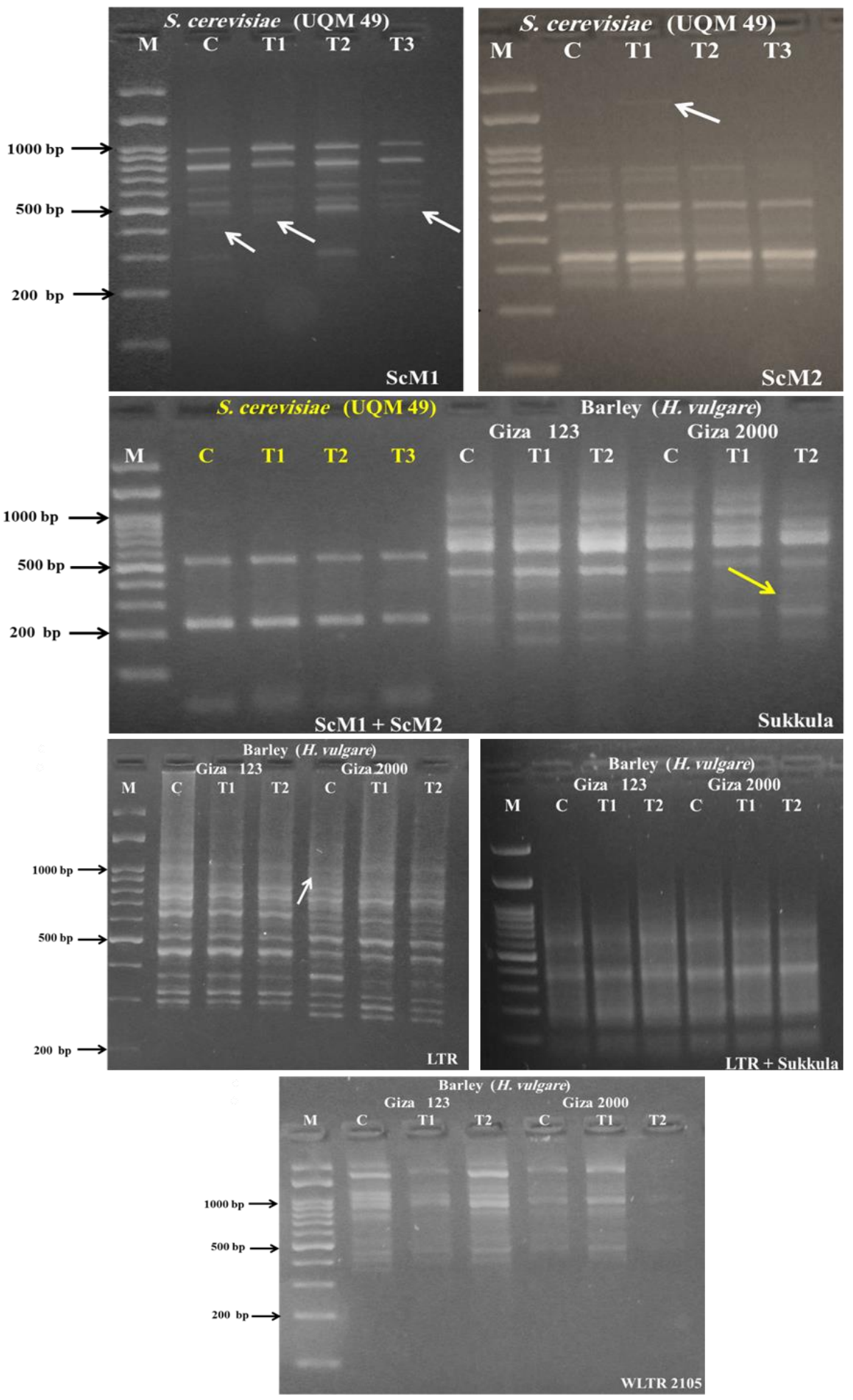

Fig. 1. IRAP banding patterns for yeast (ScM1, ScM2 and ScM1+ScM2 primers) and barley (LTR, Sukkula, Wltr2105 and LTR+Sukkula primers) under the control (C), $0.5 \mathrm{M}(\mathrm{T} 1), 1 \mathrm{M}$ (T2) and $1.5 \mathrm{M} \mathrm{NaCl}$ (T3) for yeast, whereas, under the control, $0.25 \mathrm{M} \mathrm{(T1)} \mathrm{and} \mathrm{0.6} \mathrm{M} \mathrm{NaCl} \mathrm{(T2)} \mathrm{for} \mathrm{barley} \mathrm{cultivars;} \mathrm{Giza-123} \mathrm{and}$ Giza-2000. The arrows refer to the different "polymorphic" bands. 

Stress using IRAP and SCOT Markers

From the previous IRAP results, four primers showed different bands between the control and treatments while the other primers gave the same bands with both the control and treatments such as Wltr2105 primer and the combinations LTR + Sukkula and ScM1 + ScM2. ScM1 primer with yeast gave two different bands, one of them with molecular size 456 bp was present only in $\mathrm{T} 1(0.5 \mathrm{M})$, that mean there is new retrotransposition due to this level of salinity. While the other band was found in the control and absent from any treatments, as shown in Fig. (1) and Table (5). With ScM2 primer only one band with molecular size 1952 bp appeared in only in $\mathrm{T} 1$, that mean there is new retrotransposition due to this level of salinity. In barley, only one different band appeared with each primer. Giza-123 didn't show any different bands between the control and treatments with any primer, whereas Giza-2000 exhibit one different band with each primer (Fig. 1 and Table 6).

\section{Start Codon Targeted Polymorphism (SCoT)}

Is a new PCR-based technique for detection polymorphism developed by Collard and Mackill, 2009. SCoT analysis depends on the short conserved regions around the start codon (ATG). Nine SCoT primers (Table 4) were used to study the efficiency of SCoT technique in the i) detection of the differences in the transposition rate due to salinity stress, and ii) determination if these differences are related to the coding regions in the yeast and barley genomes? Fig. (2) and Tables (7 and 8) illustrate the different bands which appeared / disappeared under the salinity stress compared with the normal conditions for both yeast (Fig. 2 and Table 7) and barley (Fig. 2 and Table 8).

SCOT results of yeast showed that the eight from nine primers gave different bands between the control and treatments; as an example; SCoT7 showed three bands with molecular sizes 1042, 390 and $300 \mathrm{bp}$ respectively, the first band was found only in treatment 1 while it was absent in the control and other treatments, the second band was found only in treatment 1 and treatment 2 while it absent in both the control and treatment 3, the third band found only in treatment 2. Each of SCoT 31,32 and 34 displayed only one different band between the control and treatments as shown in Fig. (2) and Table (7).
Table 7. The molecular sizes of different bands of yeast SCoT primers

\begin{tabular}{|c|c|c|c|c|c|}
\hline Primer & Bp & C & T1 & T2 & T3 \\
\hline \multirow{2}{*}{ SCoT 5 } & 1091 & 1 & 1 & 1 & 0 \\
& 313 & 0 & 1 & 0 & 0 \\
\hline \multirow{3}{*}{ SCoT 7 } & 1042 & 0 & 1 & 0 & 0 \\
& 390 & 0 & 1 & 1 & 0 \\
& 300 & 0 & 0 & 1 & 0 \\
\hline \multirow{2}{*}{ SCoT 18 } & 784 & 0 & 1 & 0 & 0 \\
& 462 & 1 & 0 & 1 & 1 \\
\hline \multirow{2}{*}{ SCoT 22 } & 1630 & 1 & 0 & 0 & 0 \\
& 366 & 1 & 1 & 1 & 0 \\
\hline & 814 & 1 & 0 & 0 & 1 \\
& 423 & 1 & 0 & 0 & 1 \\
SCoT 26 & 350 & 1 & 0 & 0 & 1 \\
& 321 & 0 & 0 & 0 & 1 \\
& 271 & 1 & 0 & 0 & 0 \\
\hline SCoT 31 & 1911 & 0 & 1 & 0 & 0 \\
SCoT 32 & 844 & 1 & 0 & 0 & 0 \\
SCoT 34 & 517 & 1 & 0 & 1 & 1 \\
\hline
\end{tabular}

Table 8. The molecular sizes of different bands of barley SCoT primers

\begin{tabular}{|c|c|c|c|c|c|c|c|}
\hline \multirow{2}{*}{ Primer } & \multirow{2}{*}{ Bp } & \multicolumn{3}{|c|}{ Giza-123 } & \multicolumn{3}{c|}{ Giza-2000 } \\
\cline { 3 - 7 } & & C & T1 & T2 & C & T1 & T2 \\
\hline SCoT 5 & 462 & 0 & 0 & 0 & 1 & 0 & 0 \\
\hline \multirow{5}{*}{ SCoT 7 } & 1374 & 1 & 1 & 0 & 0 & 1 & 0 \\
& 1131 & 1 & 0 & 0 & 0 & 1 & 0 \\
& 1042 & 0 & 0 & 0 & 0 & 1 & 0 \\
& 281 & 1 & 0 & 0 & 0 & 1 & 0 \\
\hline \multirow{2}{*}{ SCoT 26 } & 1762 & 0 & 1 & 1 & 0 & 0 & 0 \\
& 1594 & 0 & 1 & 0 & 0 & 0 & 0 \\
\hline SCoT 31 & 564 & 0 & 0 & 0 & 0 & 1 & 1 \\
\hline \multirow{5}{*}{ SCoT 32 } & 1488 & 0 & 0 & 0 & 1 & 0 & 0 \\
& 1161 & 0 & 0 & 0 & 1 & 1 & 0 \\
& 1000 & 0 & 0 & 0 & 1 & 0 & 0 \\
& 977 & 0 & 0 & 0 & 0 & 1 & 1 \\
& 844 & 1 & 0 & 1 & 0 & 0 & 0 \\
\hline \multirow{5}{*}{ SCoT 34 } & 472 & 0 & 0 & 1 & 0 & 0 & 0 \\
& 437 & 0 & 1 & 0 & 0 & 0 & 0 \\
& 360 & 0 & 0 & 0 & 0 & 1 & 1 \\
& 332 & 1 & 0 & 0 & 0 & 0 & 0 \\
\hline SCoT 35 & 710 & 0 & 0 & 0 & 1 & 0 & 1 \\
\hline
\end{tabular}

Whereas in barley, there are two primers didn't show different bands between the control and treatment, but the other primers gave different bands between them such as, SCoT 35 didn't show any different bands in Giza-123 between the control and treatments, whereas it showed one polymorphic band that appeared in both the control and treatment two but absent in treatment 1 as shown in Fig. (2) and Table (8). 

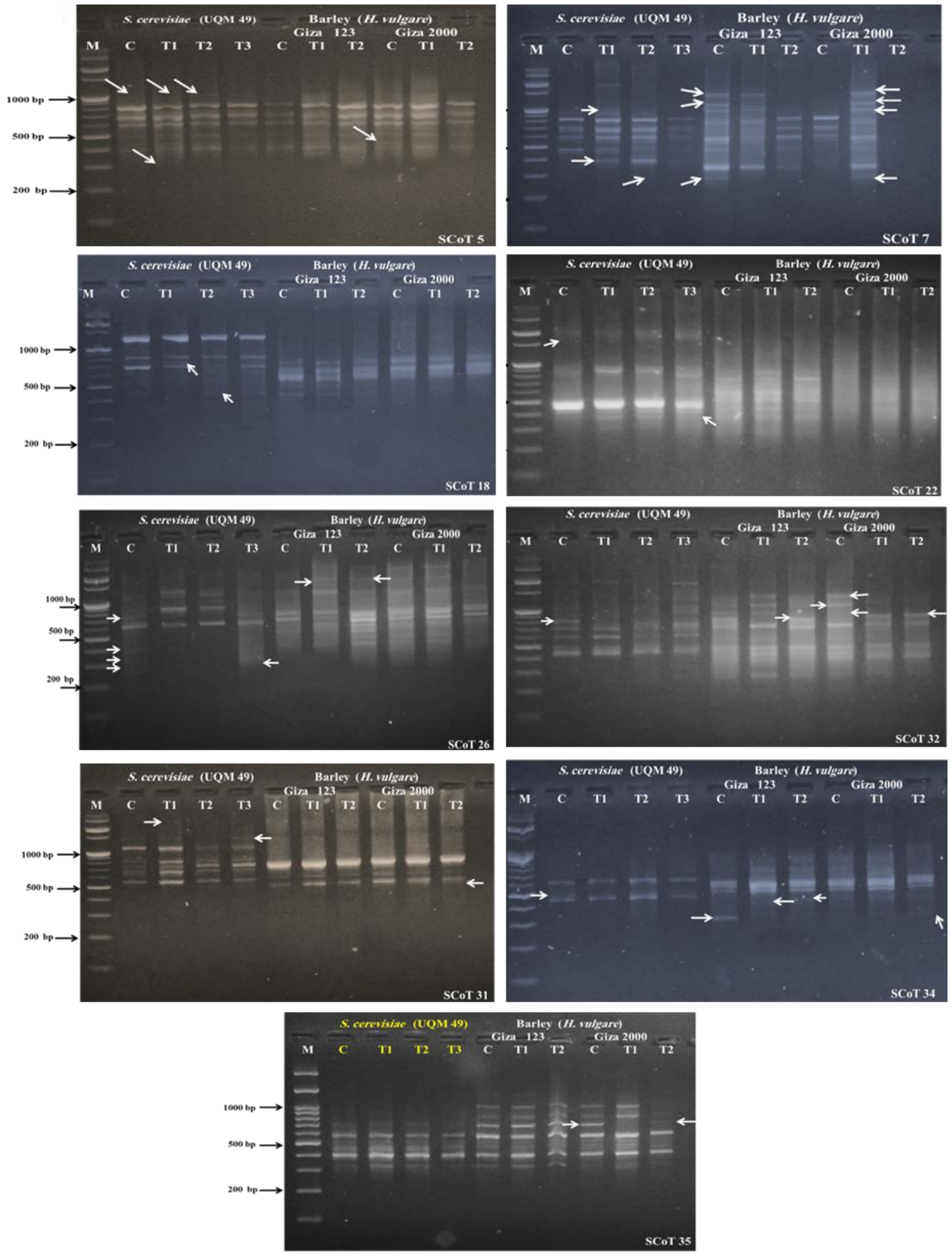

Fig. 2. SCoT banding patterns for yeast strain and barley cultivars under the control (C), $0.5 \mathrm{M}$ (T1), $1 \mathrm{M}$ (T2) and $1.5 \mathrm{M} \mathrm{NaCl}$ (T3) for yeast and under the control, $0.25 \mathrm{M} \mathrm{(T1)} \mathrm{and} 0.6 \mathrm{M} \mathrm{NaCl}$ (T2) for barley cultivars; Giza-123 and Giza-2000. The arrows refer to the different "polymorphic" bands. 

Stress using IRAP and SCoT Markers

The results which obtained in this research are in agreement with Bayram et al (2012), where they found activation in mobilization of Nikita retrotransposon where they used different ages of calli that originated from the same embryo and at the same time. Their results showed that the conditions of tissue culture caused this retrotransposition activation. Kartal-Alacam et al (2014) cultured mature barley embryos (Hordeum vulgare L.) for callus formation. They investigated Sukkula (a non autonomous retrotransposon) polymorphism in calli with different culturing time using IRAP technique, their results showed that conditions of tissue culture and the age of callus affected on the movements of Sukkula retrotransposon. Our results also exhibit that salinity stress cause retrotransposon movements.

On the other hand, SCoT marker is a new PCR-based technique developed for the polymorphism detection. This method based on conserved regions around the ATG regions (Sadek and Ibrahim, 2018). Our result showed that SCoT markers are a good method for distinguished between the different bands in the control and several treatments due to salinity stress.

Wu et al (2013) considered SCoT technique as modern way for differential expression of genes. They predict that, the SCOT markers will be a promising method to discover the novel genes. This investigating agreed with our results that showed presence of new patterns due to the stress and exhibit an effect of Retrotransposons on coding regions.

This study applied to confirm that PCR techniques can exhibit the activation of retrotransposition due to salinity stress. The obtained data from this result represents that not only real time PCR technique can detect the retrotransposition due to different stresses but we can use other techniques that be easy, fast, cheap and effectiveness for detect retrotransposition and the effect of these elements on other coding regions, like IRAP and SCoT techniques. These techniques achieve these purposes and gave good positive results and we recommend using these techniques for different purposes due to their advantage.

\section{CONCLUSION}

Environmental stresses have been reported to activate retrotransposons. In this study, IRAP technique; retrotransposons-based technique and SCOT markers confirmed the effect of salinity stress on the movement of retrotransposons on other coding regions. Salinity stress affect on retrotransposons movement and on coding genes. IRAP and SCoT are suitable PCR - markers for detect the retrotransposition and the effect on other regions.

\section{REFERENCES}

Al-qurainy F., Khan S., Nadeem M. and Tarroum M. 2015. Scot Marker for the Assessment of Genetic Diversity in Saudi Arabian Date Palm Cultivars. Pak. J. Bot., 47(2), 637-643.

Alzohairy A.M., Yousef M.A., Edris S., Kerti B., Gyulai G. and Bahieldin A. 2012. Detection of LTR retrotransposons reactivation induced by in vitro environmental stresses in Barley (Hordeum vulgare) via RT-qPCR. Life Sci. J., 9(4), 5019-5026.

Bayram E., Yilmaz S., Hamat-Mecbur H., KartalAlacam G. and Nermin Gozukirmizi 2012. Nikita retrotransposon movements in callus cultures of barley (Hordeum vulgare L.) POJ, 5(3), 211-215.

Beringer J.E. 1974. R factor transfer in Rhizobium leguminosarum. J. Gen. Microbial., 84, 188198.

Bonchev G., Georgiev S. and Pearce S. 2010. Retrotransposons and ethyl methanesulfonateinduced diversity in hexaploid wheat and triticale. Cent. Eur. J. Biol., 5(6), 765-776.

Collard B.C.Y. and Mackill D.J. 2009. Start codon targeted (SCOT) polymorphism: A simple, novel DNA marker technique for generating genetargeted markers in Plants. Plant Mol. Biol. Rep., 27, 86-93.

Curran B.P.G. and Virginia Bugeja 2006. Basic yeast protocols investigations in Saccharomyces cerevisiae. In Xiao, W. $2^{\text {nd }}$ ed., Methods in Mol. Biol., (313). Humana Press Inc. Totowa, New Jersey, USA.

Dellaporta S.L., Wood J. and Hicks J.B. 1983. A plant DNA minipreparation: Version II. Plant Molecular Biology Reporter, 1(4), 19-21. Doi: 10.1007/s11105-008-0060-5.

Feschotte C., Jiang N. and Wessler S.R. 2002. Plant transposable elements: where genetics meets genomics. Nat. Rev. Genet., 3, 329341.

Hirochika H., Okamoto H. and Kakutani T. 2000. Silencing of retrotransposons in Arabidopsis and reactivation by the ddm1 mutation. Plant Cell, 12, 357-369. 
Ikeda K., Nakayashiki H., Takagi M., Tosa Y. and Mayama S. 2001. Heat shock, copper sulfate and oxidative stress activate the retrotransposon AMGGY resident in the plant pathogenic fungus, Magnaporthe grisea. Molecular Genetics and Genomics, 266(2), 318325.

Kalendar R. and Schulman H.A. 2006. IRAP and REMAP for retrotransposon-based genotyping and fingerprinting. Nature Protocols, 1(5), 2478- 2484.

Kalendar R., Tanskanen J., S. Immonen, E. Nevo and Schulman A.H. 2000. Genome evolution of wild barley (Hordeum spontaneum) by BARE-1 retrotransposon dynamics in response to sharp microclimatic divergence. Proc. Natl. Acad. Sci., 97(12), 6603-6607.

Kaminker J.S., Bergman C.M., Kronmiller B., Carlson J., Svirskas R., Patel S., Frise E., Wheeler D.A., Lewis S.E., Rubin G.M., Ashburner M. and Celniker S.E. 2002. The transposable elements of the Drosophila melanogaster euchromatin: a genomics perspective. Genome Biol., 3(12), Research0084. Doi: 10.1186/gb-2002-3-12-research0084.

Kartal-Alacam G., Yilmaz S., Marakli S. and Gozukirmizi N. 2014. Sukkula retrotransposon insertion polymorphisms in Barley 1. Russian $\mathbf{J}$. of Plant Physiology, 61(6), 828-833.

Kim J.M., Vanguri S., Boeke J.D., Gabriel A. and Voytas D.F. 1998. Transposable elements and genome organization: a comprehensive survey of retrotransposons revealed by the complete Saccharomyces cerevisiae genome sequence. Genome Res., 8, 464-478.

Lander E.S., Linton L.M., Birren B., Nusbaum C., Zody M.C., Baldwin J., Devon K., Dewar K., Doyle M., FitzHugh W., Funke R., Gage D., Harris K., Heaford A., Howland J., Kann L., Lehoczky J., LeVine R., McEwan P., McKernan K., Meldrim J., Mesirov J.P., Miranda C., Morris W., Naylor J., Raymond C., Rosetti M., Santos R., Sheridan A. and Sougnez C. 2001. Initial sequencing and analysis of the human genome. Nature, 409, 860921.
Mansour A. 2007. Epigenetic activation of genomic retrotransposon. J. of Cell and Molecular Biology 6, 99-107.

Mansour A. 2008. Utilization of genomic retrotransposon as cladistic molecular markers. J. of Cell and Molecular Biology, 7, 17-28.

Mansour A. 2009. Water deficit induction of Copia and Gypsy genomic retrotransposons. Plant Stress, 3, 33-39.

Maumus F., Allen A.E., Mhiri C., Hu H., Jabbari K., Vardi A., Marie-Angèle Grandbastien and Bowler C. 2009. Potential impact of stress activated retrotransposons on genome evolution in a marine diatom. BMC Genomics, 10, 624628. Doi: 10.1186/1471-2164-10-624

Sabot F. and Schulman A.H. 2006. Parasitism and the retrotransposon life cycle in plants: a hitchhik's guide to the genome. Heredity, 97, 381-388.

Sabot F., Kalendar R., Jääskeläinen M., Wei C., Tanskanen J. and Schulman A.H. 2006. Retrotransposons: Metaparasites and agents of genome evolution. Isr. J. Ecol. Evol., 52, 319330.

Sadek M.S.E. and Ibrahim S.D. 2018. Genetic relationships among maize inbred lines as revealed by start codon targeted (SCoT) analysis. JIPBS, 5(1), 103-107.

Salazar M., González E., Casaretto J.A., Casacuberta J.M. and Lara S. Ruiz 2007. The promoter of the TLC1.1 retrotransposon from Solanum chilense is activated by multiple stress-related signaling molecules. Plant Cell Rep., 26(10), 1861-1868.

SanMiguel P., Gaut B.S., Tikhonov A., Nakajima Y. and Bennetzen J.L. 1998. The paleontology of intergene retrotransposons of maize. Nat. Genet., 20, 43-45.

Smit A.F. 1999. Interspersed repeats and other mementos of transposable elements in mammalian genomes. Curr. Opin. Genet. Dev., 9, 657-663.

Wu J.M., Li Y.R., Yang L.T., Fang F.X., Song H.Z., Tang H.Q., Wang M. and Weng M.L. 2013. cDNA-SCoT: A novel rapid method for analysis of gene differential expression in sugarcane and other plants [online]. AJCS, 7(5), 659-664. 


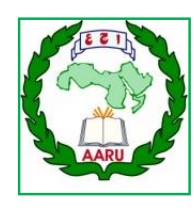

مجلة اتحاد الجامعات العربية للعلوم الزراعية، جامعة عين شمس، القاهرة، مصر مجلد(27)، عدد(5)، 2609-2601، 2019

Website: http://ajs.journals.ekb.eg

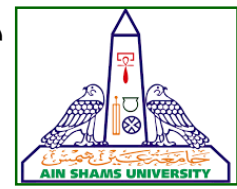

2609

قياس التغيير في معدل الانتقال الرجعي استجابة للإجهاد الملحي بإستخدام

تقنيات الـ IRAP و SCOT

[207]

مروة محمود شحاتة" - إيمان محمود فهمي - فاطمة محمد بدوي - لمياء مصطفي كمال سيد

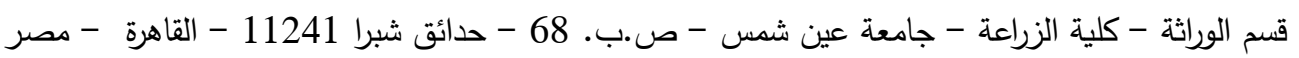

*Corresponding author: marwa gene@agr.asu.edu.eg

Received 30 October, 2019

Accepted 2 December, 2019

نفس البادئ في المقارنة فقط ولم تظهر في جميع

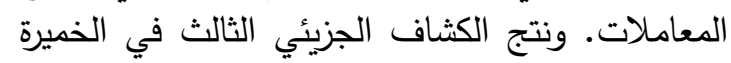

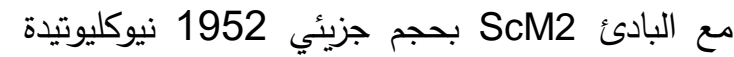
تحت مستوى ملوحة 0.5 مولار فقط. وظئ فئر كثافين جزيئين في الثعير أحدهما ظهر مع البادئ

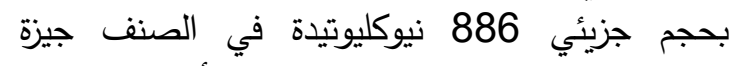
2000 في المقارنة فقيط، بينما أعطى البادئ Sukkula نفس الصنف جيزة 2000 في مستوى ملوحة 0.6 مولار فقط. أظهرت بادئات تقنية 17 SCoT كثافا

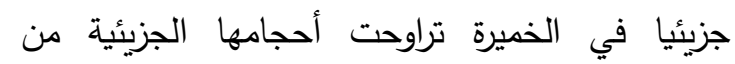

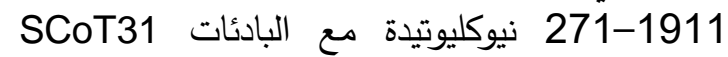
وSCoT26 على التوالي. أوضحت هذه هذه النتائج ظهور حزم مختلفة بين المقارنة والمعاملات وأن التئ التركيزات

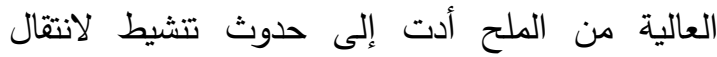

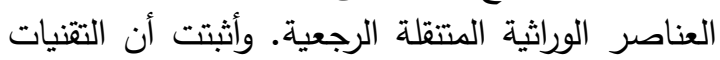

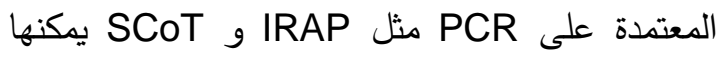
الكثف عن الانتقالات الجديدة والتي يسبيها الإجهاد

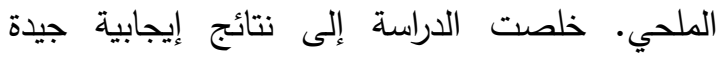

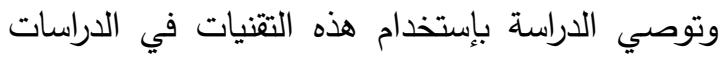

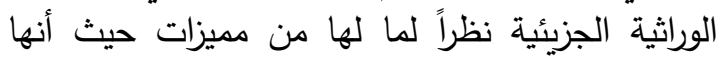
سهلة التطبيق قليلة التكلفة سريعة التتفيذ وعالية الفعالية.

الكلمات الدالة: العناصر الوراثية المتتقلة الرجعية،

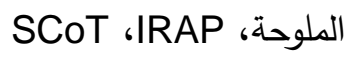

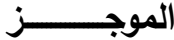

تمثل العناصر الوراثية المتنقلة الرجعية جزء كبير

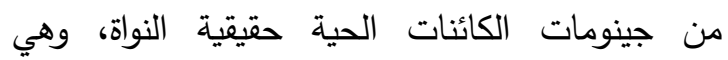

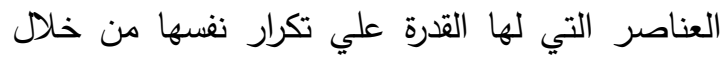

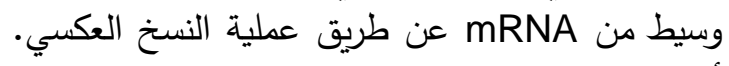

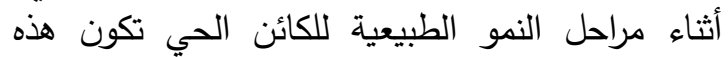
العناصر في حالة سكون ولكن عندما يتعرض الكائن الحي للضغوط البيئية فإنها تصبح أكثر نشاطا وانتقالا.

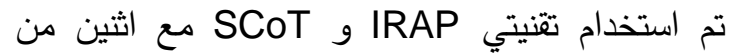
جينومات حقيقيات النواة المتحملة للملوحة هما الخميرة (Saccharomyces cerevisiae L.) (Hordeum vulgare L.) EMCC-49 من الخميرة والصنفين جيزة 123 وجيزة

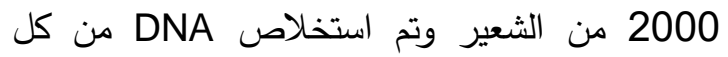

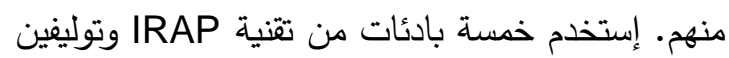
منهما وتسعة بادئات من تقنية SCOT. تم تمية سلائلة

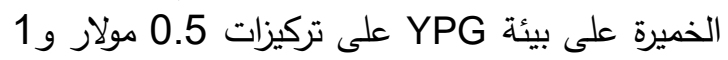

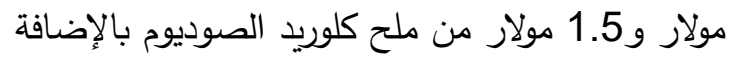
إلى المقارنة. تم ري نباتات الثعير بتركيزات 0.25

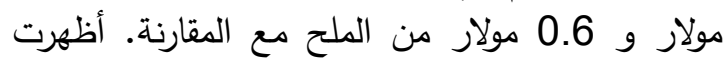

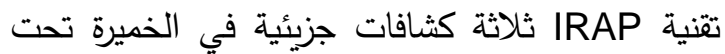

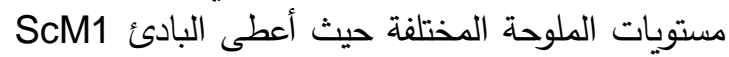
حزمة واحدة بحجم جزيئي 456 نيوكليوتيدة في الخميرة في مستوى ملوحة 0.5 مولار و 1.5 مولارة ، بلوني بينما ظهرت حزمة بحجم جزيئي 409 نيوكليوتيدة باستخدام 